\title{
Effects of surface treatment of provisional crowns on the shear bond strength of brackets
}

\author{
Josiane Xavier de Almeidaㄹ, Mauren Bitencourt Deprá1, Mariana Marquezan², Luciana Borges Retamoso³, Orlando Tanaka4
}

Objective: To assess the adhesive resistance of metallic brackets bonded to temporary crowns made of acrylic resin after different surface treatments. Methods: 180 specimens were made of Duralay and randomly divided into 6 groups $(\mathrm{n}=30)$ according to surface treatment and bonding material: G1 - surface roughening with Soflex and bonding with Duralay; G2 - roughening with aluminum oxide blasting and bonding with Duralay; G3 - application of monomer and bonding with Duralay; G4 - roughening with Soflex and bonding with Transbond XT; G5 - roughening with aluminum oxide blasting and bonding with Transbond XT and G6: application of monomer and bonding with Transbond. The results were statistically assessed by ANOVA/Games-Howell. Results: The means (MPa) were: G1= 18.04, G2= 22.64, G3 $=22.4$, G4 $=9.71$, G5 $=11.23$, G6 $=9.67$. The Adhesive Remnant Index (ARI) ranged between 2 and 3 on G1, G2 and G3 whereas in G4, G5 and G6 it ranged from 0 to 1, showing that only the material affects the pattern of adhesive flaw. Conclusion: The surface treatment and the material influenced adhesive resistance of brackets bonded to temporary crowns. Roughening by aluminum blasting increased bond strength when compared to Soflex, in the group bonded with Duralay. The bond strength of Duralay acrylic resin was superior to that of Transbond XT composite resin.

Keywords: Acrylic resins. Orthodontic brackets. Shear bond strength.

Objetivo: avaliar a resistência adesiva de braquetes metálicos colados a coroas provisórias confeccionadas em resina acrílica após diferentes tratamentos de superfície. Métodos: cento e oitenta corpos de prova foram confeccionados em Duralay e divididos aleatoriamente em seis grupos $(n=30)$, de acordo com tratamento de superfície e material de colagem: grupo 1, asperização da superfície com Soflex e colagem com Duralay; grupo 2, asperização com jato de óxido de alumínio e colagem com Duralay; grupo 3, aplicação de monômero e colagem com Duralay; grupo 4, asperização com Soflex e colagem com Transbond XT; grupo 5, asperização com jato de óxido de alumínio e colagem com Transbond XT; e grupo 6, aplicação de monômero e colagem com Transbond. Os resultados foram tratados estatisticamente pela ANOVA e pelo teste de Games-Howell. Resultados: as médias (MPa) foram: grupo 1 - 18,04; grupo 2 -22,64; grupo 3-22,4; grupo 4-9,71; grupo 5-11,23; grupo 6-9,67. O índice de remanescente adesivo (ARI) variou entre 2 e 3 nos grupos 1, 2 e 3 . Já nos grupos 4, 5 e 6 , variou entre 0 e 1, demonstrando que apenas o material influencia o padrão de falha adesiva. Conclusão: o tratamento de superfície e o material influenciaram a resistência adesiva dos braquetes colados à coroas provisórias. A asperização por jato de óxido de alumínio elevou a resistência de união quando comparada ao Soflex, no grupo colado com Duralay. A resistência adesiva da resina acrílica Duralay foi superior à da resina composta Transbond XT.

Palavras-chave: Resinas acrílicas. Braquetes ortodônticos. Resistência ao cisalhamento.

${ }^{1}$ Graduated in Dentistry, Catholic University of Paraná (PUCPR). ${ }^{2} \mathrm{PhD}$ student in Orthodontics, Federal University of Rio de Janeiro (UFRJ). ${ }^{3} \mathrm{PhD}$ in Dental Materials, Catholic University of Rio Grande do Sul (PUCRS). ${ }^{4}$ Postdoc in Orthodontics, Saint Louis University and Federal University of Juiz de Fora. Full professor at PUCPR.
How to cite this article: Almeida JX, Deprá MB, Marquezan M, Retamoso LB, Tanaka $\mathrm{O}$. Effects of surface treatment of provisional crowns on the shear bond strength of brackets. Dental Press J Orthod. 2013 July-Aug;18(4):29-34.

Submitted: June 19, 2009 - Revised and accepted: June 23, 2010

" The authors report no commercial, proprietary or financial interest in the products or companies described in this article.

Contact address: Orlando Tanaka

Rua Imaculada Conceição, 1155 - Curitiba/PR — Brazil

CEP: 80215-901 - E-mail: tanakaom@gmail.com 


\section{INTRODUCTION}

The technique of directly bonding orthodontic appliances by means of acid conditioning and composite resin became universal in the 90 s. $^{8}$ Since then, many researches have been developed with the aim of verifying the resistance of metallic brackets on dental enamel. ${ }^{2}$ Bonding in Orthodontics, although temporary, must be resistant enough to withstand orthodontic and occlusal forces. ${ }^{18}$

As a result of developments in technology regarding continuing education and communication in orthodontics, there has been an increase in the demand of adult patients seeking orthodontic treatment in the last few years, and it is not unusual to find amalgam restorations, incrustations in gold, ceramic crowns and fixed prosthesis in these patients. ${ }^{20}$

Orthodontics is oftentimes an intermediate stage to oral rehab. Thus, it becomes necessary to perform bracket bonding in temporary crowns which are generally made of self-etching acrylic resin. Newman ${ }^{11}$ asserted that the materials and techniques available are capable of effectively bonding accessories to the surface of materials other than enamel.

According to Zachrisson, ${ }^{21}$ acrylic resin is recommended for bonding on acrylic surfaces because its bonding strength is greater than that obtained with other bonding agents.

Some works in the literature focus on bracket bonding on surfaces of gold, amalgam, resin and porcelain, however, there are a few references about bonding on acrylic resin present in temporary crowns. ${ }^{3,12}$ Therefore, this work aims at assessing bond strength between brackets and acrylic resin after different surface treatments using two distinct bonding materials.

\section{MATERIAL AND METHODS}

The specimens were made of self-etching acrylic resin (Duralay/Reliance, Worth, USA). Polymethylmethacrylate and methylmethacrylate were mixed in the proportions recommended by the manufacturer (3 powder:1 fluid) in a glass recipient with lid until the mixture reached the plastic phase. Afterwards, resin was poured into standardized aluminum rings $(20 \times 20 \mathrm{~mm})$. With resin polymerization, the specimens were removed and regularized under refrigeration in 400, 600 and 1200 wet sandpaper. After the use of sandpapers, the specimens were polished with felt disc and calcium carbonate in a bench vise.

The 180 specimens were randomly divided into 6 groups (G1 to G6), according to the surface treatment and material used for bonding (Table 1).

G1 and G4 samples had their surface roughened with coarse sandpaper disc (Soflex) during 2 minutes, rinsed with air/water blasting for 15 seconds and dried with air blasting for another 15 seconds.

G2 and G5 samples had their surface roughened with $45-\mu \mathrm{m}$ aluminum oxide blasting during $45 \mathrm{sec}-$ onds, rinsed with air/water blasting for 15 seconds and dried with air blasting for another 15 seconds.

As for G3 and G6 samples, monomer was applied to the surface of specimens central region. To this end, monomer was dropped on a disposable brush which remained in contact with the acrylic surface for 5 seconds.

Thereafter, excess was removed with air blasting and orthodontic bonding was performed by a single operator, as follows.

On groups G1, G2 and G3, Duralay ${ }^{\circledR}$ acrylic resin (Reliance) was the material used for bonding. It was inserted in the base of the brackets by means of the brush technique, with accessories positioned and subjected to $400 \mathrm{gF}$ of pressure measured by a dynamometer (ETM). In order to maintain the proportion recommended by the manufacturer, $1 \mathrm{~g}$ of powder was mixed with $0.5 \mathrm{ml}$ of fluid in a Dappen dish. This measure was used for the bonding of two specimens. Excess was removed with the aid of a probe. After bracket bonding, the specimens were immediately stored in distilled water at $37^{\circ} \mathrm{C}$ for 24 hours. ${ }^{9,13}$

Conditioning was performed with phosphoric acid at 37\% (Dentalville, Joinville, Brazil) for 15 seconds on the specimens of G4, G5 and G6. After that, the surfaces were rinsed with air/water blasting for 15 seconds

Table 1 - Division of groups according to surface preparation and bonding resin.

\begin{tabular}{ccc}
\hline Group & Surface preparation & Bonding resin \\
\hline G1 & Soflex sandpaper disc & Duralay \\
G2 & Aluminum oxide & Duralay \\
\hline G3 & Monomer & Duralay \\
G4 & Soflex sandpaper & Transbond XT \\
G5 & Aluminum oxide & Transbond XT \\
G6 & Monomer & Transbond XT \\
\hline
\end{tabular}


and dried with air blasting for another 15 seconds, followed by the application of Transbond adhesive (3M/ Unitek $\left.^{\circledR}\right)$. Transbond XT ${ }^{\circledR}\left(3 \mathrm{M} /\right.$ Unitek $\left.^{\circledR}\right)$ light-activated resin was inserted in the base of the brackets $(3 \mathrm{M} /$ Unitek $^{\circledR}$ ) according to the manufacturer's instructions. It was positioned and subjected to $400 \mathrm{gF}$ of pressure measured by a dynamometer (ETM) (Fig 1). Excess was removed with the aid of a probe and the resin was lightactivated for 40 seconds, 10 seconds in each face. Once bracket bonding had been finished, the specimens were stored in distilled water at $37^{\circ} \mathrm{C}$ for 24 hours..$^{9,13}$

The specimens were subjected to shear test with guillotine system at a speed of $0.5 \mathrm{~mm} / \mathrm{min}$ in a Uni- versal Testing Machine (EMIC DL500, São José dos Pinhais, Paraná, Brazil) connected to a computer (Fig 2). Strength value was obtained at the moment of bond rupture. Then, it was recorded and converted into MPa by means of specific calculations.

Bond failure was observed by a single operator through a stereomicroscope with magnification of $40 \mathrm{X}$. The Adhesive Remnant Index (ARI) was analyzed as suggested by Årtun and Bergland, ${ }^{1}$ where 0 indicates no adhesive remnant in the dental structure; 1 , less than half of remnant in the dental structure; 2 , more than a half of remnant in the dental structure and 3 , all the adhesive remnant adhered to the bracket base.

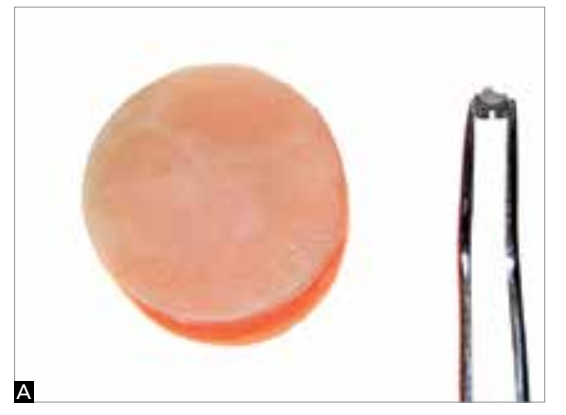

Figure 1 - Sequence of bonding, A) bond the material thickness, C) specimen.


Figure 2 - A) shear bond strength test, B) specimen positioned in the testing machine 


\section{RESULTS}

Kolmogorov-Smirnov static test revealed that variables related to bond strength presented normal distribution, except for G1. Comparison of mean values was performed through two-way ANOVA.

The yielded results showed that the value of $\mathrm{F}$ was statistically significant $(p<0.05)$ for the variables "material" and "treatment". Thus, Games-Howell test of multiple comparison was used to identify the differences, since the measures did not present homogeneous distribution (Levene test) (Table 2).

The Adhesive Remnant Index (ARI) in G1, G2 and $\mathrm{G} 3$ ranged between 2 and 3, whereas in G4, G5 and $\mathrm{G} 6$ it ranged between 0 and 1. As distribution was not normal, Kruskal Wallis test was used. No significant difference $(p>0.05)$ was found for surface treatment. Mann-Whitney $U$ test showed significant difference $(\mathrm{p}<0.05)$ with regard to the material used for bonding. Duralay had bond strength increased (Table 3).

The Spearman coefficient of linear correlation was 0.5 , which shows a regular correlation between bond strength and ARI.

Table 2 - Mean, standard deviation and p value for adhesive resistance of groups.

\begin{tabular}{ccc}
\hline Group & Mean \pm standard deviation & Statistics \\
G1 & $18.04 \pm 3.46$ & A \\
G2 & $22.64 \pm 4.04$ & B \\
G3 & $22.41 \pm 3.95$ & $\mathrm{~A}, \mathrm{~B}$ \\
G4 & $9.71 \pm 2.11$ & $\mathrm{C}$ \\
G5 & $11.23 \pm 2.75$ & $\mathrm{C}$ \\
G6 & $9.67 \pm 1.95$ & $\mathrm{C}$ \\
\hline
\end{tabular}

Different letters indicate statistically significant difference for the Games-Howell test $(p<0.05)$

Table 3 - Mean, standard deviation and p value for the Adhesive Remnant Index (ARI) of groups.

\begin{tabular}{ccc}
\hline Group & Mean \pm standard deviation & Statistics \\
G1 & $2.84 \pm 0.46$ & $\mathrm{~A}$ \\
G2 & $2.94 \pm 0.09$ & $\mathrm{~A}$ \\
G3 & $2.70 \pm 0.95$ & $\mathrm{~A}$ \\
G4 & $0.71 \pm 0.09$ & $\mathrm{~B}$ \\
G5 & $0.03 \pm 0.05$ & $\mathrm{~B}$ \\
G6 & $0.77 \pm 0.15$ & $\mathrm{~B}$ \\
\hline
\end{tabular}

Different letters indicate statistically significant difference for Mann-Whitney $U$ test $(p<0.05)$

\section{DISCUSSION}

After acid conditioning was discovered, ${ }^{3}$ the processes of adhesion to dental surfaces have improved. Adhering brackets to enamel or other structures depends on some factors such as preparation of the surface, adhesive and material used for bonding, among others. ${ }^{19}$

In this study, it was observed that pre-treating the acrylic resin surface affects bond strength. In the group in which the surface was roughened by aluminum oxide blasting, the adhesive resistance was statistically superior $(p<0.05)$ to the surface treated with Soflex, when bonding was performed with Duralay. It is probable that aluminum oxide was capable of creating deeper slots that caused the bonding material to adhere to the acrylic resin, making the bond between bracket and bonding material the weak link of the adhesive process. ${ }^{5}$

Surface preparation by chemical variation was performed in accordance with Cunningham and Benington $^{8}$ and Takahashi et al, ${ }^{17}$ who recommended the use of dichloromethane solvent to increase acrylic resin bond strength. Thus, in this research, the prior application of monomer generated an adhesive resistance similar to that obtained after roughening with Soflex, a fact that disagrees with Spratley ${ }^{16}$ and Chung et al, ${ }^{7}$ who asserted that wetting the surface with monomer alone would not increase adhesive resistance in denture base. Additionally, they indicated the necessity of rugosities on the surface of prosthesis in order to obtain an acceptable adhesive resistance. This difference is probably due to the level of strength to which it will be subjected because, in previous works, the prosthesis were subjected to masticatory loads, different from the present research in which the level of applied strength was lower.

The surface treatment did not change the adhesive resistance when the composite resin was used as bracket bonding material. This can be explained by the short-term storage of the temporary crown made of acrylic resin before bracket bonding. According to Gegauff and Wilkerson, ${ }^{10} 24$ hours of storage is not capable of altering the mechanical properties of the acrylic, thus, resistance remains even with the use of different surface preparations.

The adhesive resistance of brackets bonded to temporary materials must be strong enough to resist dental movement without debonding the orthodontic acces- 
sory, and weak enough to be removed without damaging the surface after orthodontic treatment is finished. ${ }^{4}$ According to Reynolds ${ }^{15}$ and Whitlock et al ${ }^{18}$ clinically acceptable adhesive resistance ranges between 5 and 8 $\mathrm{MPa}$, which indicates that any surface treatment used in this research can be clinically used. Moreover, acrylic or composite resin maintains bond strength above the level accepted for clinical use. ${ }^{15,18}$

The present research obtained increase in the shear bond strength when bracket bonding was performed with acrylic resin. This can be explained by the fact that no other material was used, since adhesive resistance increases when materials of similar chemical components are used, ${ }^{6}$ because material's cohesive power is substantially higher than adhesion strength obtained by adding another bonding agent. Thus, the results of the present study agree with Zachrisson ${ }^{21,22}$ who asserted that acrylic is the recommended bonding material for bonding performed in acrylic surfaces, regardless of the type of bracket. However, this increase in bond strength (18.04 to $22.64 \mathrm{MPa}$ ) favors the integrity of the temporary crown surface, since the adhesive remnant remains in the restoration. In this situation, the ARI ranged between 2 and 3 .

On the groups bonded with Transbond XT composite resin, the adhesive resistance was statistically lower. This procedure is similar to repairs carried out on acrylic prosthesis. When a relatively new material has been just polymerized and polished, it presents slightly over $50 \%$ of non-reactive methacrylate groups. However, as time goes by, there will be less non-reactive methacrylate groups, which will generate few crosslinks with the new material in- serted and reduction in the capacity of the monomer in penetrating the matrix. Thus, resistance between the temporary crown material and the resin inserted in the base of the bracket is reduced in about $50 \%{ }^{10}$

Reduction in adhesive resistance makes it difficult to remove the accessory without damaging the temporary restoration because failure occurs in the interface temporary crown/resin, a fact that is confirmed by the Adhesive Remant Index, which ranged between 0 and 1 .

The outstanding differences obtained on ARI showed an opposite pattern of debonding, which resulted in regular correlation between this index and the adhesive resistance. Thus, it can be asserted that adhesive resistance increases with acrylic resin being used as bonding material. As a consequence, the amount of material on the temporary crown also increases, facilitating the preservation of the buccal surface. However, the material will need to be mechanically removed by the professional. Despite the differences found in shear bond strength of brackets bonded to temporary crowns made with acrylic resin, additional studies are warranted to further investigate this topic.

\section{CONCLUSION}

Both the surface treatment and material influenced bond strength of metallic brackets bonded to temporary crowns made with self-etching acrylic resin. Roughening performed with aluminum oxide blasting increased bond strength when compared to Soflex, in the group bonded with Duralay. Bond strength of Duralay acrylic resin was superior to that of Transbond XT composite resin. 


\section{REFERENCES}

1. Artun J, Bergland S. Clinical trials with crystal growth conditioning as an alternative to acid-etch enamel pretreatment. Am J Orthod. 1984;85(4): 333-40

2. Bengtson NG, Bengtson AL, Carvalho DS, Rossetto SM. Estudo comparativo da força adesiva de quatro materiais para colagem de braquetes. Rev Dental Press Ortod Ortop Facial. 2003:8(3):43-7.

3. Bisaggio GKGC, Marassi C. Colagem direta de braquetes ortodônticos uma revisão [monografia]. Rio de Janeiro (RJ): UNIGRANRIO; 2003.

4. Buonocore MG. A simple method of increasing the adhesion of acrylic filling materials to enamel surface. J Dent Res. 1955;34(6):849-53.

5. Chay SH, Wong SL, Mohamed N, Chia A, Yap AU. Effects of surface treatment and aging on the bond strength of orthodontic brackets to provisional materials. Am J Orthod Dentofacial Orthop. 2007:132(5):577.e7-11.

6. Chen HL, Lai YL, Chou IC, Hu CJ, Lee SY. Shear bond strength of provisional restoration materials repaired with light-cured resins. Oper Dent. 2008:33(5):508-15.

7. Chung RW, Clark RK, Darvell BW. The bonding of cold-cured acrylic resin to acrylic denture teeth. Aust Dent J. 1995:40(4):241-5.

8. Cunningham JL, Benington IC. An investigation of the variables which may affect the bond between plastic teeth and denture base resin J Dent. 1999:27(2):129-35.

9. Fox NA, McCabe JF, Buckley JG. A critique of bond strength testing in orthodontics. Br J Orthod. 1994:21(1):33-43.

10. Gegauff AG, Wilkerson JJ. Fracture toughness testing of visible lightand chemical-initiated provisional restoration resins. Int J Prosthodont $1995: 8(1): 62-8$.
11. Newmam GV. Bonding to porcelain. J Clin Orthod. 1983:17(1):53-5.

12. Noronha MP, Masioli DLC, Almeida MAO. A influência do silano na colagem de braquetes metálicos em superfície de resina acrílica. Braz Oral Res. Supplement. Proceedings of the 22nd Annual SBPqO Meeting. São Paulo, 2005. v. 19, p. 114

13. Pashley DH, Tay FR. Aggressiveness contemporary self-etching adhesives: Part II. Dent Mater. 2001:17(5):430-44.

14. Phillips RW. Restorative resins: repair of composites. In: Dyson J, editor. Skinner's science of dental materials. Philadelphia: W. B. Saunders; 1991. p. 235.

15. Reynolds IR. A review of direct orthodontic bonding. Br J Orthod. 1975:2(3):171-8

16. Spratley $\mathrm{MH}$. An investigation of the adhesion of acrylic resin to dentures J Prosthet Dent. 1987:58(3):389-92

17. Takahashi Y, Chai J, Takahashi T, Habu T. Bond strength of denture teeth to denture base resins. Int J Prosthodont. 2000;13(1):59-65.

18. Whitlock BO, Eick JD, Ackerman RJ Jr, Glaros AG, Chappell RP. Shear strength of ceramic brackets bonded to porcelain. Am J Orthod Dentofacial Orthop. 1994:106(4):358-64

19. Wickwire NA, Rentz D. Enamel pretreatment: a critical variable in direct bonding systems. Am J Orthod. 1973;64(5):499-512.

20. Zachrisson BU, Buyukyilmaz T. Recent advances in bonding to gold, amalgam and porcelains. Am J Orthod. 1993:27(3):661-75

21. Zachrisson BU. Bonding in orthodontics. In: Graber TM, Swain BF Orthodontic current and principles and techniques. St. Louis: C.V. Mosby; 1985. p. 485-563.

22. Zachrisson BU. Orthodontic bonding to artificial tooth surfaces: clinical versus laboratory findings. Am J Orthod Dentofacial Orthop. 2000:117(5):592-4. 